UDK: 81:81'282.8

Stručni rad

Primljeno: 15. 7. 2021.

Prihvaćeno za štampu: 12. 12. 2021.

Dr. sc. Hatidže Burnić, vanr. prof.

Univerzitet u Bihaću

batidze_b@hotmail.com

\title{
TEORIJSKI TEMELJI KONTAKTNE LINGVISTIKE
}

\section{Sažetak}

Riječ stranog porijekla ulazile su u pojedine jeqike u razlicitim periodima jezičkog $i$ kulturno-historijskog razvoja, pod razlicitim okolnostima, iz razlicitih rąloga ili potreba, te na različite načine. Istraživanjem lingvističke literature i rječnika nailazimo na razlicite definicije i tumačenja pojma jezički kontakt. Iz tog razloga u uvodnom dijelu rada se na osnovu relevantne literature definira pojam jezički kontakt uključujući i definiranje pojma kontaktne lingvistike kao grane koja se bavi istraživanjem jeaickih kontakata. Slijedi problematiziranje jezičkog $i$ leksičkog posudivanja kao posljedica jezičkih kontakata te razloga jezičkog posudivanja i tipova jezičkih posudenica.

Ključne riječi: jerički kontakt, kontaktna lingvistika, jeričko posudivanje

\section{Uvod}

\section{Poimanje jezičkog kontakta}

Osnovni pojam kontaktne lingvistike jest jezički dodir ili jezički kontakt za koji u literaturi, nažalost, ne nalazimo jednoznačne definicije.

U Metzler Lexikon Sprache nalazimo sljedeću definiciju riječi Sprachkontakt (jezički kontakt) ${ }^{1}$ :

«Das Aufeinandertreffen zweier oder mehrerer Sprachen meist durch geographische Nachbarschaft ihrer Sprecher. Vorraussetzung ist, dass

${ }^{1}$ Svi prijevodi u radu su urađeni od strane autorice. 
Kommunikation über die Grenzen der jeweiligen einzelnen Sprachgemeinschaft hinweg erfolgt.» ${ }^{2}$

Iz njegove definicije se podrazumijeva da je to „međusobni kontakt“ dvaju ili više jezika. Kao posljedice jezičkog kontakta navode se dvojezičnost, interferencije, jezičko miješanje, nastanak jezičkog saveza, zamjena jezika.

U Lexikon der Sprachwissenschaft nalazimo definiciju riječi Sprachkontakt (jezički kontakt) potpuno uopćenu:

«Koexistenz zweier oder mehrerer Sprachen innerhalb einer Sprachgemeinschaft, deren Sprecher diese Sprachen alternativ verwenden $»^{3}$.

Ova definicija potvrđuje mišljenje ostalih lingvista da učesnici jezičkih kontakata nisu svi govornici, već bilingvalni govornici, tj. oni koji koriste najmanje dva jezika aktivno u određenim situacijama.

Dejvid Kristal (David Crystal) u Enciklopedijskom rečniku moderne lingvistike koristeći termin jezički kontakt referira na «situaciju geografskog kontinuiteta ili velike društvene bliskosti (te stoga uzajamnog utjecaja) između jezika ili dijalekata». Dalje ističe da se rezultat kontaktnih situacija može odraziti lingvistički, u porastu broja pozajmljenica, obrascima fonološke i gramatičke promjene, mješovitim oblicima jezika, i općem povećanju bilingvizma raznih vrsta. (Kristal 1985: 129)

Herman Paul (Hermann Paul) u djelu Prinzipien der Sprachgeschichte koristeći termin Sprachmischung (miješanje jezika) smatra da do jezičkog kontakta dolazi čim dvije osobe započnu razgovor:

\footnotetext{
2 „Dodir dvaju ili više jezika najčešće je rezultat geografske blizine njihovih govornika. Preduvjet je uspostava komunikacije preko granica pojedinih jezičkih područja." (prijevod H. B.)

3 ,Jezički kontakt je koegzistencija dvaju ili više jezika unutar jedne jezičke zajednice, čiji govornici koriste ove jezike alternativno. (prijevod H. B.)
} 
«Gehen wir davon aus, dass es nur Individualsprachen gibt, so können wir sagen, dass Sprachmischung stattfindet, sobald sich überhaupt zwei Individuen miteinander unterhalten.» ${ }^{4}$

Paul smatra da je uslov za jezičko miješanje i jezički kontakt da osoba ima određeni minimum vladanja stranim jezikom kako bi se jezički kontakt mogao ostvariti. (Hermann: 1966)

Uriel Weinreichevo djelo Jezici u kontaktu, prvi put objavljeno 1953. godine, od centralnog je značaja za istraživanje poimanja jezičkog kontakta i dvojezičnosti. U prevedenom djelu Sprachen in Kontakt navodi se:

"Die Praxis, abwechselnd zwei Sprachen zu gebrauchen, soll Zweisprachigkeit heißen, die an solcher Praxis beteiligten Personen werden zweisprachig genannt.»

Prema Uriel Weinreichu, jezici u kontaktu su oni koje naizmjenično upotrebljava isti govornik. Tu osobu naziva bilingvom, a pojavu bilingvizmom. Posljedicu te pojave da jedan govornik upotrebljava više jezika naziva interferencijom. (Weinrich 1953/1977)

O jezičkom kontaktu i preuzimanju iz jedne jezičke grupe u drugu pisao je i Leonard Blumfild (Leonard Bloomfield) u svom djelu Language (1958). On koristi izraz culture borrowing (kulturno pozajmljivanje). Sam termin „kulturno“ ukazuje na to da je jezički kontakt u vezi s vanjezičkim faktorima. Blumfild se ograničava na kulturne uzroke jezičkog kontakta i uvodi to, da svaka jezička zajednica uči od svojih komšija. Kulturna i civilizacijska dostignuća jedne jezičke zajednice se prenose na druge jezičke zajednice.

Prema Rudolfu Filipoviću (1986: 17), jezički kontakt je:

«kada se neka riječ ili fraza jezika davatelja preuzme u jezik primatelja ili kada govornik odluči naučiti strani jezik. Njegova definicija također upućuje na dvojaku prirodu jezičkog kontakta: individualnu $i$ kolektivnu».

Bechert i Wildgen (1991) navode tri razine na kojima dolazi do jezičkih kontakata: razinu govora (parole), razinu jezika (langue) i razinu

${ }^{4}$ „Ako pretpostavimo da postoje samo pojedinačni jezici, onda do jezičkog miješanja dolazi kada dvije individue započnu razgovor.“ (prijevod H. B.) 
jezičkog razvoja, koji se odnosi na dijahronijski razvoj jezičkih sistema $\mathrm{u}$ intenzivnim kontaktima s drugim jezičkim sistemima nakon dugog vremenskog utjecaja jezičkih kontakata. (Bechert - Wildgen : 1991)

Neki teoretičari kontaktne lingvistike (Weiss, Oksaar, Scotton Okeju) smatraju da ne dolazi do kontakta između jezika, nego između govornika različitih jezika i predlažu umjesto termina Sprachkontakt (jezički kontakt) da se koristi termin Sprecherkontakt (dodir govornika).

U području vezanom za jezičke kontakte razvile su se i razne tipologije jezičkih kontakata. Asim Peco (1986: 56) raščlanjuje jezičke kontakte u tri tipa: migracijski tip dodira, nestalni kontaktni tip i stalni granični tip dodira. Za glavni kriterij svoje klasifikacije uzima posljedice jezičkih dodira, tj. da li postoji jezički kontakt samo na leksičkoj razini, dolazi li do strukturnih promjena u jeziku ili čak do bilingvizma. K. Ehlich (1992: 67-69) razlikuje čak do deset tipova jezičkog kontakta.

Prema svemu navedenom, možemo konstatovati da je izraz jezički kontakt ili jezički dodir zapravo apstraktan pojam koji označava kontakt ili komunikaciju između govornika različitih jezika, bilo da se radi o aktivnoj komunikaciji ili o pasivnoj izloženosti jeziku koji govorniku nije maternji jezik.

\section{Kontaktna lingvistika}

Lingvističku granu koja se bavi problematikom vezanom za istraživanja jezičkih dodira u bosanskom jeziku obično nazivamo teorija jezika $u$ kontaktu prema naslovu knjige Rudolfa Filipovića Teorija jezika u kontaktu (1986) kreatora osnovnog modela proučavanja stranih jezičkih elemenata u bosansko-hrvatsko-srpskim jezicima ${ }^{5}$.

\footnotetext{
5 Naziv bosansko/hrvatsko/srpski jezik je korišten prema uzoru i cilju Midhata Riđanovića koji u svom djelu Jezik i njegova struktura opravdava zamjenu naziva jezika „srpsko-hrvatski jezik“ s nazivom b,h,s. „Jezik koji se koristio na prostorima Bosne i Hercegovine u bivšoj Jugoslaviji obično se zvao srpsko-hrvatski. Rezultat stvaranja novih država na teritoriji bivše Jugoslavije ozvaničeni su novi nazivi njihovih jezika: bosanski, odnosno hrvatski, odnosno srpski““. Iz navedenih razloga, takav naziv je upotrebljavan u ovom dijelu rada, s obzirom da se objavljene knjige $\mathrm{i}$ saznanja odnose i na bosanski jezik, koji je predmet ovog rada. Ako se, ipak, nešto
} 
Rudolf Filipović u svom uvodnom dijelu monografije bilježi da je preuzeo termin iz naslova djela Uriela Weinreicha Languages in contact (1953). On smatra da su termini lingvističko ili jezičko posuđivanje (linguistic or language borrowing) neprecizni i da termin jezici $u$ kontaktu daje šire značenje. Iz tih razloga uvodi termin kontaktna lingvistika (language contacts) referirajući na granu lingvistike koja istražuje kontakte jezika (language contacts) u teoriji i primjeni. Ta grana lingvistike obuhvata i proučava cijelo područje jezičkih kontakata i jezičkih sukoba (language contact - language conflict), bilingvizam i multilingvizam, prevođenje i usvajanje drugih jezika, sve oblike interferencije koji se javljaju kao rezultat jezičkih kontakata i kultura na svim razinama. Čini nam se da su ovi nabrojani i mnogi drugi razlozi opravdali formiranje posebne grane lingvistike. (Filipović: 1986)

Brojni drugi lingvisti su dali svoj doprinos ovom području. Tokom vremena su prošireni i drugi termini kao što su kontaktna lingvistika (prema engl. contact linguistic), lingvistika jezičkih kontakata ili kontaktologija, a u posljednje vrijeme sve se više koriste i nazivi lingvistika jezičkih dodira te dodirna lingvistika. Među bosanskim lingvistima ne postoji jedinstveno stajalište koji bi termin bio najprihvatljiviji, premda se nama praktičnim čini termin kontaktologija zbog svoje jednočlanosti i tvorbene plodnosti (kontaktolog, kontaktološki).

Wildgen kontaktnu lingvistiku definira kao područje interakcije humanističkih i društvenih nauka i naglašava važnost makrogeografskih i makrokulturoloških struktura te individualnopsiholoških i mikrofizioloških procesa.

Piškorec kontaktnu lingvistiku definira kao disciplinu u kojoj svoje mjesto nalaze psiholingvistički $i$ sociolingvistički, antropološki, komunikološki i književno-naučni pristupi i metode. (Piškorec: 2001)

Pod kontaktologijom (Contact Linguistics) Rudolf Filipović smatra da je to:

odnosi samo na hrvatski, ili samo na srpski, ili samo na bosanski jezik, upotrijebljen je odgovarajući naziv jezika. 
"grana lingvistike koja na osnovu rezultata istraživanja tih kontakata formulira lingvističke principe vezane uz bilingvizam, jezičko posuđivanje, usvajanje jezika, gubljenje jezika, napuštanje jednog $u$ korist drugog, pod pritiskom dominantnog jezika ili jezika prestiža, jezičko planiranje itd».

\section{Jezičko posuđivanje}

Posuđivati se mogu elementi svih jezičkih razina, tj. svaka jezička jedinica (fonem, morfem, leksem, sintagma, fraza, rečenica...) može se preuzeti iz jednog jezika u drugi, postati sastavni dio tog jezika i utjecati na širenje jezičkog fonda i druge segmente kao i svaka domaća jezička jedinica. Istraživanja su, međutim, pokazala da se posuđivanje najčešće odvija na leksičkoj razini. Pri jezičkim kontaktima se prvo posuđuje leksik, a tek u slučaju dužeg i intenzivnijeg kontakta dolazi i do posuđivanja fonema, morfema ili drugih obilježja.

Meillet, kao i mnogi drugi lingvisti, smatra posve prirodnim leksičko posuđivanje, ali posuđivanje u području glasova i gramatike smatra rijetkim. On argumentuje svoje tvrdnje ovako: "Svaki jezik je jedan sistem, i bilingvalni govornici koji imaju izbor od dva jezika ne miješaju ta dva jezika.» Dalje tvrdi da izgovor i gramatika čine zatvoreni sistem i na kraju zaključuje da su predmet posuđivanja upravo elementi rječnika i da nema jezika čiji leksik ne sadrži posuđenice. (Filipović: 1986)

Nezaobilazna literatura, kada je riječ o jezičkom posuđivanju, je djelo Prinzipien der Sprachgeschichte (Načela jezičke historije) od Hermanna Paula. Prema njemu su posljedice jezičkog kontakta ,jezičko miješanje“ (Sprachmischung) i „miješani jezici“ (Mischsprache). On smatra da je miješanje jezika bitno za život jezika. U svom djelu on razvija načela jezičkog posuđivanja i definira utjecaj miješanje jezika ovako:

«Jedan jezik utječe na drugi ako drugi prima strani materijal i ako se njegov vlastiti jezični materijal formira prema stranim uzorima.»

Dalje navodi da lingvističko posuđivanje može biti rezultat potrebe i mode. U daljem izlaganju Paul opisuje ulazak strane riječ u jezik koji je primalac. On koristi termin supstitucija glasova kada je riječ o modificiranju oblika riječi. Pod naslovom glasovna supstitucija 
(Lautsubstitution) iznosi načela po kojima se sa stajališta glasovnog sistema posuđenice uključuju u sistem jezika primaoca.

Sredinom 19. vijeka dolazi do žestokih rasprava o problemu miješanje jezika. Meillet, Schönfelder, Haugen kao i mnogi drugi lingvisti kritiziraju korištenje pojma miješanje jezika, smatraju ga nepogodnim i nestvarnim. Njihova istraživanja pokazuju da se u većini slučajeva miješaju leksički elementi, a da to nije slučaj s fonološkim, morfološkim ili sintaktičkim elementima.

Iz tih razloga K. H. Schönfelder razlikuje preuzimanje leksičkih elemenata od ostalih, te podrazumijeva pod terminom miješanje jezika kada pored leksičkih elemenata dođe do preuzimanja i ostalih gramatičkih elemenata. Preuzimanje samo leksičkih elemenata on naziva posuđivanje.

E. Haugen upozoravajući na slabost i neispravnost predlaže odbacivanje termina miješanje i predlaže termin posuđivanje (borrowing). U svom teoretskom članku The Analysis of Linguistic Borrowing precizno definira termin lingvističko posuđivanje te ga opisuje kao proces koji se odvija kad bilingvalni govornik reproducira uzorak jednog jezika u drugom. Njegova terminologija konačno dovodi do zamjene dotadašnjeg ustaljenog termina miješanje jezika s novim nazivom jezičko posuđivanje koje se do danas koristi.

Naslanjajući se na teoriju Haugena, Rudolf Filipović definira jezičko posuđivanje ovako:

«Kad je element X prešao iz jezika davalaca u jezik primalaca ili je jezik primalac posudio element X od jezika davaoca, kažemo da je nastupila interferencija između jezika davalaca i jezika primalaca».

\section{Leksičko posuđivanje i tipovi leksičkih posuđenica}

Postoje različiti tipovi leksičkih posuđenica. Najčešće se posuđuju u cjelini, odnosno izraz s pripadajućim sadržajem, ali je moguće posuditi i samo sadržaj koji se zatim pridružuje već postojećoj domaćoj riječi. U tom slučaju govorimo o semantičkom posuđivanju i semantičkim posuđenicama. Poseban tip posuđivanja jest prevođenje jezičnih znakova leksičkim sredstvima jezika primatelja. Njih nazivamo prevedenice ili kalkovi. Dakle, pod leksičkim posuđivanjem 
podrazumijevamo preuzimanje leksičke jedinice, njezina izraza ili sadržaja, ili pak i izraza i sadržaja (Dabo-Denegri: 1998)

Nazivi ili termini koji se odnose na leksičke jedinice preuzete iz drugih jezika kao npr. posuđenice, tuđice, usvojenice, pozajmljenice, strane riječi, strani leksik, prevedenice itd., neujednačeno se koriste, različito se definiraju i klasificiraju. To proizlazi iz različitih kriterija, prema kojima se leksičke jedinice razvrstavaju i s kojom namjerom se istražuju i analiziraju. Prema svemu navedenom se i koncipiraju razne metodologije i tipologije.

Istraživački radovi koji tematiziraju leksičko istraživanje stranih riječi u bosanskom jeziku su prvenstveno koncipirani teorijskom podlogom studije Rudolfa Filipovića Jezici u kontaktu odnosno njegovom terminologijom i modelom jezičkog posuđivanja. Iako ne možemo nabrojati sve postojeće termine, metode i klasifikacije leksičkog posuđivanja, ovom prilikom ćemo iznijeti one što smatramo najbitnijim i za ovo istraživanje relevantnim.

O jezičkom posuđivanju Filipović ističe tri osnovna elementa od kojih treba da polazi svako jezičko istraživanje. Oslanjajući se na mišljenje Uriela Weinreicha, Filipović ističe da su jezici u kontaktu oni koje naizmjenično upotrebljava isti govornik. Tu osobu naziva bilingvom, a tu pojavu bilingvizmom. Posljedicu te pojave da jedan govornik upotrebljava više jezika naziva interferencijom.

Element (riječ) X kako ga izgovaraju govornici jezika davalaca zove model, a posuđen element kako ga izgovaraju govornici jezika primalaca naziva replikom.

Kad dva jezička sistema dođu u međusoban dodir dolazi do preuzimanja riječi iz jednog jezika u drugi. Dva jezika koja sudjeluju u tom procesu naziva jezik davatelj i jezik primatelj.

Pri primanju leksema iz jezika davaoca u jezik primaoca, događaju se određene promjene na različitim razinama. Bez obzira na razine, sveukupne promjene mogu se globalno podijeliti u dvije skupine: primarne $i$ sekundarne. Prema tome, razlikujemo primarnu $\mathrm{i}$ sekundarnu adaptaciju, prema modelu Filipovića. Za opis razdoblja procesa trajanja promjena, bilo modela ili replike, koristi se pojam faza. $\mathrm{U}$ fazi primarne adaptacije, posuđenica se prilagođava sistemu jezika 
primatelja, dok u fazi sekundarne adaptacije ona postaje podložna promjenama na različitim razinama kao i bilo koja druga domaća riječ. Sve promjene koje se događaju prije nastanka replike nazivamo primarna adaptacija, a sve promjene koje slijede na replici ubrajamo $\mathrm{u}$ sekundarnu adaptaciju.

Primarna adaptacija je jasno određena. Ona počinje ulaskom stranog modela u bosanski jezički sistem jezika primatelja i završava formiranjem replike. Sekundarna adaptacija je jasna samo što se tiče postanka. Završetak se ne može odrediti jer se replika može mijenjati u toku razvoja jezika primatelja. Te promjene se ne povezuju više sa stranim jezikom jer su (nadalje) uvijek vezane samo za jezički sistem primatelja i ponašaju se prema njegovim pravilima.

Filipović razlikuje četiri načina adaptacije kroz koje model prolazi: fonološka, ortografska, morfološka i semantička. Prema tim razinama su imenovani procesi: transfonemizacija, transmorfemizacija $i$ transsemantizacija. (Filipović: 1986)

\section{Razlozi leksičkog posuđivanja}

$\mathrm{B} / \mathrm{h} / \mathrm{s}$ leksikološka literatura obično dijeli razloge leksičkog posuđivanja na izvanjezičke i unutarjezičke kao što su političke, trgovačke, kulturno-civilizacijske veze ili geografska blizina između dvije jezičke zajednice, te unutarjezičke koje se odnose na prazna mjesta u sistemu koja se popunjavaju gotovim rješenjima iz drugih jezika (Samardžija, 1998).

Rudolf Filipović smatra da do jezičkog posuđivanja može doći iz jednostavne potrebe za imenovanjem predmeta ili izuma koji je preuzet iz druge kulture, često materijalno superiornije, jer je uslijed njegova preuzimanja došlo do ,praznog mjesta“ u sistemu jezika primatelja. Osim toga, jezičko posuđivanje može biti i rezultat pomodnosti.

Weinreich leksičko posuđivanje objašnjava univerzalnom potrebom za imenovanje novih entiteta. On, također, navodi niz unutarjezičkih motiva za posuđivanje: učestalost pojedinih riječi, štetna homonimija, trajna potreba za sinonimijom. Od psiholingvističkih motiva ističe: nedovoljna diferenciranost pojedinih značenjskih polja, društveni status jezika davatelja ili primatelja kao i puki nemar govornika. 
E. Öhmann razlikuje luksuzne i nužne posuđenice (Luxuslehnwörter und Bedürfnislehnwörter). Luksuzne posuđenice su one za koje već postoji domaći ekvivalent pa je posuđenica „suvišna“. A nužne posuđenice su one za koje nema u jeziku primatelja adekvatna zamjena, te postoji razlog za posuđivanje i opravdanje radi popunjavanja leksičke praznine u jeziku primatelju. (Štebih-Golub: 2010)

Bloomfield (1933) za opravdano posuđivanje koristi termin kulturno posuđivanje. On još navodi intimno i dijalekatsko posuđivanje.

R. Deroy objašnjava razloge za leksičko posuđivanje terminima: praktična nužnost (practical necessity) i emocionalna potreba (emotional needs). Praktičnom nužnošću motivirano je posuđivanje leksema kojima se označavaju novi entiteti. O posuđivanju zbog emocionalnih potreba riječ je pri posuđivanju uzrokovanom psiholingvističkim i sociolingvističkim razlozima kao npr. prestižom jezika davatelja. (Štebih-Golub: 2010)

Polazeći od spoznaje da se riječi ne posuđuju samo da bi se imenovalo nešto novo, već da posuđivanje može biti motivirano i konotativnom te emocionalnom vrijednošću riječi. E. Andrić (1996) navodi niz razloga za leksičko posuđivanje: imenovanje novih stvari i pojmova; preuzimanje strane riječi u interesu preciznog izražavanja; izražavanje pripadnosti nekoj skupini povezanoj zajedničkim interesima; izražavanje bliskosti; intimnosti; olakšanje komunikacije; pobuđivanje pažnje slušatelja ili čitatelja; želja za postizanjem raznovrsnosti u jeziku; nedostatak jezičke kulture i nemarnost; želja za identifikacijom i imitacija neke poznate osobe; nepoznavanje adekvatne domaće riječi; nepoznavanje tačnog značenja strane riječi i stoga nemogućnost da je zamjeni adekvatnom domaćom riječi; svjesno prilagođavanje višoj ili nižoj razini izražavanja sagovornika. (Štebih-Golub: 2010)

Neki lingvisti ne prihvataju sve motive za posuđivanje stranih riječi. Mnogi su mišljenja da nema potrebe za stranim leksikom ukoliko ima adekvatna zamjena. Na temelju purističke literature Samardžija (1998: 63) utvrđuje pravila koja se tiču prihvatanja i neprihvatanja posuđenica: «Posuđenice su jeziku potrebne ako za njih nema domaće zamjene ili je zamjena zastarjela. Postoji li domaća zamjena opsegom svoga sadržaja ista posuđenici, odnosno radi li se o sinonimima, prednost u upotrebi ima domaća riječ. Ako je opseg sadržaja posuđenice širi ili uži od 
opsega sadržaja domaćeg leksema, treba je upotrijebiti samo onda kada je domaći leksem ne može zamijeniti»

S druge strane, mnogo lingvista opravdava posuđivanje iz bilo kojeg razloga argumentirajući da je svako posuđivanje provedeno s razlogom i da leksičko posuđivanje uvijek ispunjava neku komunikacijsku potrebu i time postaje opravdano.

\section{Zaključak}

Iz svega navedenog možemo zaključiti da proučavanje leksičkih posuđenica zauzima glavno mjesto u tradiciji kontaktne lingvistike.

Naime, ne postoji jezik koji u svojoj leksičkoj građi ne sadrži i jedinice preuzete iz drugih jezika. Tu pojavu uvjetuje otvorenost leksičkog podsistema, za razliku od strukturalno strogo definiranog fonološkog, morfološkog ili sintaktičkog sistema nekog jezika. Osim otvorenosti posuđivanje olakšava i denotativna funkcija elemenata u podsistemu. Riječi se uvijek referiraju na izvanjezičku stvarnost, stoga pojava novih stvari i pojmova dovodi do novih leksema bilo kreiranjem bilo posuđivanjem.

\section{Literatura}

Bechert Johannes, Wildgen Wolfgang (1991) Einführung in die Sprachkontaktforschung, Wissenschaftliche Buchgesellschaft, Darmstadt. Bloomfield Leonard (1958) Language, Henry Holt and Company, New York. Bußmann, Hadumod (2002) Lexikon der Sprachwissenschaft. Alfred Kröner Verlag, Stuttgart.

Čedić, Ibrahim et al. (2007) Rječnik bosanskog jezika. Institut za jezik, Sarajevo.

Dabo-Denegri, Ljuba (1998) Jezičko posuđivanje - tipologija leksičkih posuđenica. Filogogija 30-31, HAZU, Zagreb.

Ehlich, Konrad (1992) Kommunikationsbrüche, Vom Nachteil und Nutzen des Sprachkontakts, Zielsprache Deutsch 2, str. 64-74.

Filipović, Rudolf (1967) Jezici u kontaktu i jezično posuđivanje. Savremena lingvistika IV, Zagreb, str. 27-89. 
Filipović, Rudolf (1986) Teorija jezika u kontaktu. JAZU- Školska knjiga, Zagreb.

Glück, Helmut (2010) Metzler Lexikon Sprache, J.B. Metzler Verlag, Stuttgart-Weimar.

Hermann, Paul (1966) Prinzipien der Sprachwissenschaft, Max Niemeyer, Tübingen.

Kristal, Dejvid: Enciklopedijski rečnik moderne lingvistike. Nolit, Beograd

Peco, Asim (1986) Germanizmi u Vukovu Srpskom rječniku iz 1852. Filologija, 14, JAZU, Zagreb, str. 271-282.

Piškorec, Velimir (2001) Temeljni pojmovi dodirnoga jezikoslovlja, Strani jezici, Hrvatsko filološko drušvo, Zagreb.

Riđanović, Midhat (1998) Jezik i njegova struktura, Šahinpašić, Sarajevo.

Samardžija, Marko (1995) Leksikologija, Školska knjiga, Zagreb.

Štebih-Golub, Barbara (2010) Germanizmi u kajkavskome književnom jeziku, Institut za hrvatski jezik i jezikoslovlje, Zagreb.

Weinreich, Uriel (1977) Sprachen in Kontakt: Ergebnisse und Probleme der Zweisprachigkeitsforschung, Verlag C. H. Beck, München. 
Hatidže Burnić, PhD

University of Bihac

batidze_b@hotmail.com

\title{
THEORETICAL FOUNDATIONS OF CONTACT LINGUISTICS
}

\begin{abstract}
Words of foreign origin entered certain languages in different periods of linguistic and cultural-historical development, under different circumstances, for different reasons or needs, and in different ways. By researching the linguistic literature and dictionaries, we come across different definitions and interpretations of the term 'linguistic contact'. The following is the problematization of linguistic and lexical borrowing because of linguistic contacts, and the reasons for linguistic borrowing and types of linguistic borrowings.
\end{abstract}

Keywords: contact linguistics, linguistic borrowing, lexical borrowing 


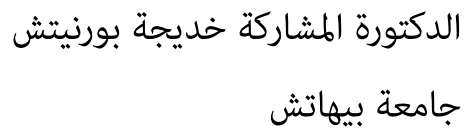

hatidze_b@hotmail.com

الأسس النظرية لعلم اللغة التواصلي

\section{الخلاصة}

تداخلت الكلمات ذات الأصل الأجنبي في لغات معينة خلال فترات مختلفة من التطور اللغوي

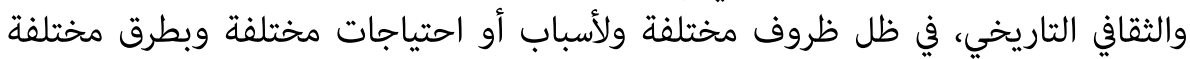

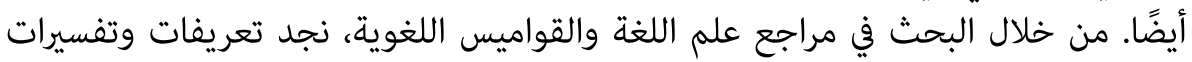

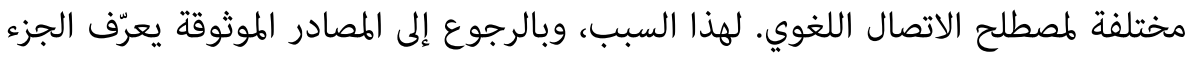

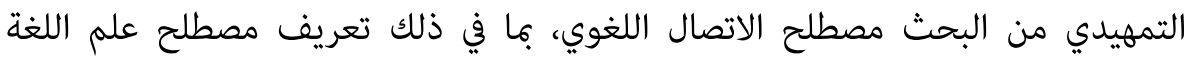

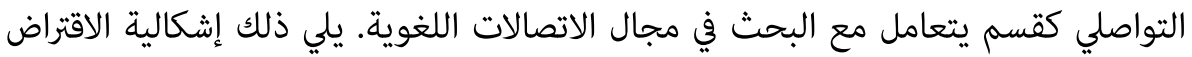

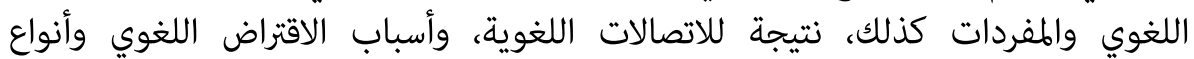
الاقتراضات اللغوية أيضًا. الكلمات المفتاحية: الاتصال اللغوي، علم اللغة التواصلي، الاقتراض اللغوي. 